\title{
Lorenzo García Aretio, Bases, mediaciones y futuro de la educa- ción a distancia en la sociedad digital, UNED, Editorial Síntesis, Madrid 2014, ss. $318^{*}$
}

Kształcenie na odległość doczekało się w hiszpańskojęzycznej literaturze naukowej wielu ciekawych i wartościowych opracowań. Instytucją, która dała impuls do prowadzenia badań nad tym modelem edukacji, zarówno w Hiszpanii, jak i w Ameryce Łacińskiej, był Narodowy Uniwersytet Kształcenia na Odległość (Universidad Nacional de Educación a Distancia - UNED), utworzony w 1972 roku. Dążąc do ciągłego rozwoju tej hiszpańskiej uczelni, jej badacze przywiązywali dużą wagę do analizy realizowanego kształcenia, jego metodyki oraz otrzymywanych rezultatów. Dzięki temu powstało wiele specjalistycznych publikacji podejmujących temat zdalnego nauczania w poszczególnych oddziałach UNED (tzw. centrach stowarzyszonych). Nie oznacza to jednak, że rezygnowano z prób całościowego ujęcia wspomnianej problematyki, ukazującego nie tylko praktyczne doświadczenia konkretnych instytucji, w tym przypadku UNED, ale również odnoszącego się do podstaw teoretycznych edukacji zdalnej. Badaczem, który miał szczególne zasługi w tejże materii, jest Lorenzo García Aretio, uznawany obecnie za jednego z najważniejszych hiszpańskojęzycznych autorów, analizujących w swych badaniach specyfikę kształcenia na odległość. W dorobku posiada blisko 50 książek (jako samodzielny autor, współautor bądź redaktor) oraz ponad 90 artykułów. Swą aktywność naukową związał z hiszpańskim UNED, gdzie od lat poświęca się pracy dydaktycznej, badawczej, zajmując przy okazji wiele ważnych stanowisk. W uznaniu jego wkładu dla rozwoju kształcenia na odległość w regionie Ameryki Łacińskiej, tamtejsze uczelnie przyznały mu wiele znaczących wyróżnień (wśród nich, dwa doktoraty honoris causa).

"Niniejszy tekst powstał w trakcie stażu badawczego realizowanego na Uniwersytecie Świętego Tomasza w Bogocie (Universidad Santo Tomás) w ramach programu Unii Europejskiej Erasmus Mundus Akcja 2. 
W 2014 roku ukazała się najnowsza książka hiszpańskiego profesora zatytułowana Bases, mediaciones y futuro de la educación a distancia en la sociedad digital (Podstawy, formy przekazu i przyszłość kształcenia na odległość $w$ społeczeństwie cyfrowym). Publikacja ta stanowi zaktualizowaną oraz znacząco poszerzoną wersję książki La educación a distancia: de la teoría a la práctica (Ksztatcenie na odlegtość: od teorii do praktyki) z 2001 roku, która cieszyła się dużym zainteresowaniem i uznaniem czytelników, stanowiąc częste źródło odwołań w literaturze przedmiotu. Renoma autora oraz jakość jego najnowszej publikacji sprawiły, iż jej premiera na rynku wydawniczym została zauważona, doczekując się wielu entuzjastycznych recenzji w hiszpańskich oraz iberoamerykańskich czasopismach naukowych. Warto więc, by również polscy czytelnicy mieli okazję zapoznać się z ogólną charakterystyką tej książki.

Swą publikację rozpoczyna García Aretio od próby uporządkowania podstawowych terminów związanych z kształceniem na odległość (rozdział I). Dokonuje krótkiego omówienia bogatego nazewnictwa, jakim zwykło się w literaturze przedmiotu określać niniejszy model nauczania, a następnie przywołuje jego najważniejsze definicje sformułowane przez międzynarodowych badaczy. Na koniec, w oparciu o powtarzające się elementy owych koncepcji oraz indywidualne doświadczenia i przemyślenia, tworzy własną charakterystykę, wyszczególniając najważniejsze - jego zdaniem - aspekty zdalnej edukacji. W rozdziale drugim przedstawiona zostaje ewolucja historyczna nauczania na odległość w poszczególnych regionach świata. Autor rozpoczyna swoje refleksje od modelu kształcenia korespondencyjnego, kończy zaś na masowych otwartych kursach online (Massive Open Online Course - MOOC). Dwa kolejne rozdziały - poświęcone teoriom naukowym, na których opiera się omawiany tu model (rozdział III) oraz czynnikom zapewniającym jego jakość i skuteczność (rozdział IV) - stanowią dopełnienie rozważań autora na temat tytułowych podstaw kształcenia na odległość.

Zawarty w tytule publikacji hiszpański termin mediaciones odnosi się do tych aspektów rzeczywistości edukacyjnej, które pośredniczą w transmisji wiedzy między konkretną instytucją a osobą uczącą się. Mowa tu więc zarówno o zastosowanych metodach kształcenia, odpowiednio dobranych pomocach edukacyjnych, jak i właściwie przygotowanym do swej roli nauczycielu/tutorze. Aspektom tym poświęcone są cztery kolejne partie tekstu. I tak, w rozdziale piątym zostaje zaprezentowana szeroka paleta środków dydaktycznych, wspierających proces kształcenia, poczynając od materiałów drukowanych, na książce elektronicznej kończąc. Następnie autor stara się spojrzeć na edukację przez pryzmat zmian społecznych, jakie doko- 
nały się za sprawą coraz bardziej innowacyjnych technologii (rozdział VI). Społeczeństwo cyfrowe, jak je nazywa, oferuje osobie nabywającej wiedzę wiele nowych narzędzi, które są w stanie wspomóc jej aktywność edukacyjną. Ich omówieniu poświęcony jest rozdział VII. Zmiany, jakie dokonują się w sferze technologicznej, co oczywiste, wpływają również na rolę i zadania nauczyciela/tutora. Refleksje nad tą właśnie kwestią stanowią treść rozdziału ósmego.

Dwa ostatnie rozdziały książki (IX, X) odnoszą się do przyszłości kształcenia na odległość, wyzwań i szans, jakie przed nim stoją. Autor przybliża czytelnikom najnowsze rozwiązania technologiczne, które w najbliższej przyszłości będą stosowane we wspomnianym modelu edukacji. Na koniec zaś, po raz kolejny podkreśla wagę odpowiedniego planowania i projektowania programów nauczania. W jego opinii jest to klucz do zapewnienia odpowiednio wysokiej jakości procesu dydaktycznego.

Jak zapewnia Lorenzo García Aretio (s. 13), jego intencją było stworzenie książki napisanej przystępnym i ciekawym językiem, która nie zatracałaby jednocześnie swego naukowego charakteru, opartego na solidnych fundamentach. Myśląc zaś o potencjalnych adresatach publikacji, kierował swą uwagę w kierunku trzech grup odbiorców: studentów i doktorantów, realizujących studia związane $\mathrm{z}$ poruszaną $\mathrm{w}$ książce tematyką, badaczy analizujących fenomen kształcenia na odległość, wreszcie do osób piastujących odpowiednie funkcje w strukturach szkolnictwa wyższego lub administracji publicznej, zainteresowanych wdrażaniem w swych instytucjach modelu edukacji zdalnej. Należy stwierdzić, iż starania autora osiągnęły pozytywny skutek. Czytelnicy otrzymują bowiem do rąk publikację dobrze przemyślaną, porządkującą stan wiedzy w temacie kształcenia na odległość. Warto sięgnąć po niniejszą książkę, będącą uwieńczeniem dotychczasowej aktywności badawczej jej autora.

Piotr Konieczny 